\title{
The Benthic Community used as Bioindicator for Assessment of the Quality of a Moroccan Coastal Ecosystem: Moulay Bousselham Lagoon
}

\author{
M. Fouad ${ }^{1 *}$, H. Bessi ${ }^{1}$ \\ ${ }^{1}$ Faculty of Sciences and Techniques of Mohammedia, \\ Department of Biology, Laboratory of Virology, \\ Microbiology and Quality / Ecotoxicology and Biodiversity, \\ BP146 Mohammedia 20650, Morocco
}

\author{
A. Benhra ${ }^{2}$, M. Bouhallaoui ${ }^{2}$ \\ ${ }^{2}$ National Institute for Halieutic Research (INRH), \\ Laboratory of Ecotoxicology, Central Laboratories, \\ Bd Sidi Abderrahmane Ain Diab, \\ Casablanca, Morocco
}

\begin{abstract}
Assessment and monitoring of the quality of lagoon systems involves a set of biological tools and parameters which aim to classify areas according to their degree of pollution. Benthic population is considered as an excellent indicator of quality of aquatic-ecosystems, due to their general characteristics and diversity. The objective of our work is to evaluate the health status of Moulay Bousselham lagoon based on its benthic population, applying biological indices (AMBI, M-AMBI, BENTIX, Trophic Index (TI)) to compare the information given by each. Our study focused on 3 stations, Rjila (st1), Sfiha (st2) and Laâcha (st3). The effect of any modification of the environment, whether natural or artificially induced, is evaluated using biological indices that allow early detection of change signals in response to any stress. All biotic indices have highlighted disturbances in the lagoon. BENTIX and M-AMBI did not allow the discrimination of stations while parameters of diversity, equitability, specific richness, as well as biological indices TI and AMBI reflected a greater imbalance for st3. The use of benthic stand in this study allowed to deduce that Moulay Bousselham lagoon is classified in an intermediate state which tends towards pollution.
\end{abstract}

Keywords - Biotic index, Trophic Index, Benthic population, AMBI, M-AMBI, BENTIX, Moulay Bousselham lagoon.

\section{INTRODUCTION}

Lagoons are ecosystems located between the continent and the sea, their ecology is characterized essentially by the hydrodynamics and the hydrochemistry resulting from the confrontation of masses of water that have different origin and chemical composition, which meddle directly on the composition, spatiotemporal structure and distribution of communities, but also on the dynamics of the various populations [1]. Lagoons are an habitat for many species, but their equilibrium can be rapidly modified under the influence of natural or anthropogenic factors; The increase in human activity has gradually led to a deterioration in the quality of these environments, in particular with regard to eutrophication, which is a process of nutrient enrichment; This process makes it difficult to maintain quality of coastal lagoons and the activities that depend on them [2].

Marine pollution occurs today in various forms (chemical, industrial and agricultural) and the sources of pollution are endless. Water then becomes inappropriate for the life of most aquatic organisms. The evaluation of the state of the lagoons with respect to eutrophication is carried out on the basis of the analysis of more than fifteen parameters distributed in the different compartments of the ecosystem: water, Sediments, plants and animals living at the bottom. Five states face to eutrophication have been defined (very good to bad) [3].

In the present research, biological indicators and biotic indices are used to collect as early as possible predictive signals of potential changes in our environment in response to what some authors define as stress in the marine environment. Research on bio-indicators involves several organisms: Plants, fish, benthic invertebrates ... Benthic populations are a good indicator of the state of their environment because of their sedentary life style and the diversity of their responses to different sources of disturbance [4]. Thus, this biological group has the advantage of being often dependent on an environment, and responds quickly to stress [5].

Bio indicators have been the subject of several harmonization work, through guidelines and conventions, such as OSPAR convention (1992) and Water Framework Directive (2000) and other agencies. Several US water quality agencies used to apply this biological material for water quality monitoring [6].

The OSPAR commission is responsible for the application of the objectives dictated by OSPAR convention, some of these objectives relate specifically to the benthic communities [7]; The WFD recommended the use of the benthic vegetation and benthic macro invertebrates for the monitoring controls [8].

Moulay Bousselham (or Merja Zerga) lagoon, located between the Rif and the Atlantic Meséta at the north-western end of the Rharb Basin, is the most important Moroccan wet area with a high biodiversity and remarkable avifaunal settlement [9]. However, this nature reserve is threatened due to human activities (pollution, intensification of agriculture, overexploitation...) which have impacted its ecological integrity [10].

Moulay Bousselham lagoon has been classified, since 1980, as a Ramsar site, a convention relating to wetlands of international importance [10], and the Ministry of Water and Forests identified Merja Zerga as a site of biological and ecological interest (SIBE) [11]. In accordance to the ecological interest of this ecosystem, several studies have been carried out on the lagoon, to contribute to the conservation of 
its resources $[12,13,14]$, the lagoon was also included in the coastal surveillance network of the National Institute of Halieutic Research (INRH).

The present work aims to contribute to the updating the qualification of the ecological status of Moulay Bousselham lagoon by using its benthic population. In addition, this work allows us to compare the pertinence of several biotic indices and their convergence.

\section{MATERIAL AND METHODS}

\section{A. Study site}

Moulay Bousselham lagoon (Merja Zerga lagoon) is the most northern coastal lagoon along the Atlantic Moroccan coast and is located approximately at $120 \mathrm{~km}$ north of Rabat, it is an elliptical tidal lagoon, located between $34^{\circ} 51^{\prime} \mathrm{N}$ latitude and $6^{\circ} 16^{\prime} \mathrm{W}$ longitude to the northwest of Morocco (Fig. 1). The lagoon covers an area of approximately $30 \mathrm{~km}^{2}$, it is composed of two merjas: the merja Kahla of $3 \mathrm{~km}^{2}$ with a depth that does not exceed $50 \mathrm{~cm}$ at high tide and the Merja Zerga of $27 \mathrm{Km}^{2}$, with a higher depth [13]. Moulay Bousselham lagoon is a Ramsar site, listed among the sites of international biological and ecological interest of the biosphere.

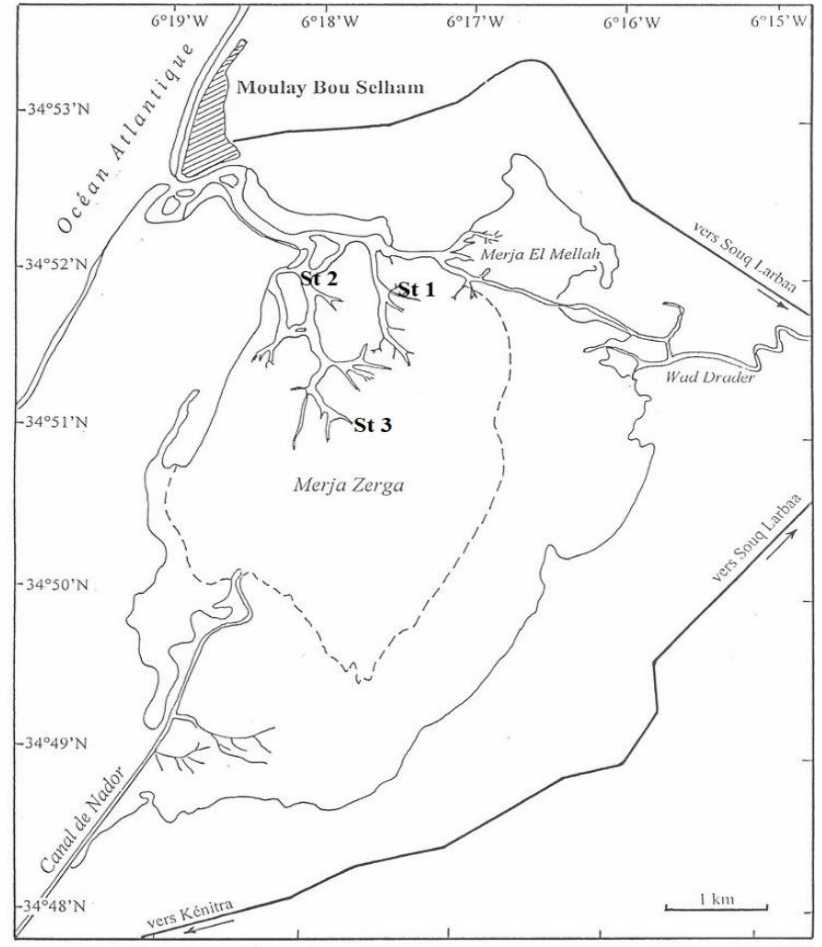

Fig. 1 Sampling site, lagoon Moulay Bousselham

\section{B. Sampling}

Sediment sampling was carried out for bio-evaluation in March 2015, at low tide, with a motorized bark. Three stations, Rjila (st1), Sfiha (st2) and Laâcha (st3), (Fig. 1) were sampled by Van Veen bucket that is appropriate in shallow muddy sediments, we established for each station two samples to obtain a composite sample; sediment samples are kept in plastic bags -on which the site and the date are recorded-and are fixed directly with $8 \%$ formalin solution to retain all organisms.
The benthic fauna are recovered in the laboratory, the samples are washed on 2 sieves superimposed at 2 different meshes $(2 \mathrm{~mm}$ and $1 \mathrm{~mm})$, and the refusal is recovered and then sorted using the binocular magnifying glass; after recovery of the individuals, we proceed to the identification of organisms by using many keys of identification (fauna of France, Worms, etc.).

\section{Data analysis and processing}

- $\quad$ Species richness (S), Abundance, Diversity index (H') and Pielou index $(\mathrm{J}$ ')

Temperature (T) and conductivity, hydrogen potential $(\mathrm{pH})$, and turbidity were determined in situ, using a field multiparameter (Hanna HI 9829).

After identifying the fauna recovered from the sediment, several synthetic indices have been calculated to show the importance of species [15]:

- $\quad$ Species richness S: represents the number of species in a stand.

- Abundance N: number of individuals of a species in a stand.

- Diversity index of Shannon and Weaver: H' is calculated according to Equation 1, taking into account the number of species present as well as their respective abundance $(\mathrm{Pi})$

$$
\mathrm{H}^{s}=-\sum_{\mathrm{i}=1}^{g}(\mathrm{Pi} \times \log 2 \mathrm{Pi})
$$

- Pielou equitability index: J' represents the ratio of the specific diversity measured using the Shannon and Weaver $(\mathrm{H})$ Index and the maximum diversity $\log 2$ $\mathrm{S}, \mathrm{J}$ ' is calculated according to Equation 2.

$$
\mathrm{J}^{\prime}=\mathrm{H}^{\prime} / \log 2(\mathrm{~S})
$$

\section{- $\quad$ Trophic Index (TI), AMBI, M-AMBI and BENTIX}

The study of the functional structure of the lagoon is based on the classification of species, adopted by Grall [16], according to the trophic levels. Different trophic groups are established according to the nature, size and state of food: predators $(\mathrm{C})$, scavengers $(\mathrm{N})$, herbivores $(\mathrm{H})$, suspension feeders (S), detritic feeders (Dt), selective deposit feeders (Ds), non-selective deposit feeders (Dss), and micrograzers ( $\mu$ B) $[13]$.

The biological indicators: Trophic Index (TI), Azti Marine Biotic Index (AMBI), Modified AMBI (M-AMBI) and BENTIX were calculated after identification of species.

Trophic Index (TI) reflects the diet of the species. Four trophic groups are determined to allow the calculation of the index, expressed as a percentage and interpreted as described in (Table 1) [17]. 
TABLE 1. INTERPRETATION OF THE PERCENTAGES OF THE TROPHIC INDEX TI [17]

\begin{tabular}{ll}
\hline TI & Status of stand \\
\hline TI $>\mathbf{6 0}$ & $\begin{array}{l}\text { The stand is normal: it is not affected by the enrichment in } \\
\text { organic matter of the sediment }\end{array}$ \\
$\mathbf{3 0}>\mathbf{T I}>\mathbf{6 0}$ & $\begin{array}{l}\text { The stand is unbalanced: it is slightly affected by the } \\
\text { enrichment in organic matter of the sediment }\end{array}$ \\
$\mathbf{T I}<\mathbf{3 0}$ & $\begin{array}{l}\text { The stand is disturbed: it is affected by the degradation of } \\
\text { the sediment due to an over-enrichment of organic matter }\end{array}$ \\
\hline
\end{tabular}

It is a numerical description of the behavior of the groups in the environment, and is calculated by the Equation 3 [18]:

$$
\mathrm{TI}=100-[33,33 *((0 \mathrm{n} 1+1 \mathrm{n} 2+2 \mathrm{n} 3+3 \mathrm{n} 4) /(\mathrm{n} 1+\mathrm{n} 2+\mathrm{n} 3+\mathrm{n} 4))]
$$

Where $\mathrm{n} 1$ through $\mathrm{n} 4$ are the number of individuals found in Feeding Groups 1-4; the coefficients in the numerator of the equation $(0,1,2,3)$ are scaling factors.

The method of ecological groups and biotic indices described by Grall [19] was carried out to evaluate the state of degradation of macro benthic stands, it is based on the grouping of the species into five groups of different pollusensitivity. The species in each group have the same ecological behavior for organic pollution and have similar profiles of abundance on the organic matter overload gradient.

The calculation of the biotic coefficient for AMBI developed by Borja [20] is based on the relative abundance of each ecological group relative to its total abundance in the sample, the values obtained for this index range from 0 to 7 . The biotic coefficient for AMBI is calculated by the Equation 4:

$\mathrm{AMBI}=(0 * \% \mathrm{GEI}+1,5 * \% \mathrm{GEII}+3 * \% \mathrm{GEIII}+4,5 \% \mathrm{GEIV}+6 * \% \mathrm{GEV}) / 100$ $\% \mathrm{GI}, \% \mathrm{GII}, \% \mathrm{GIII}, \% \mathrm{GIV}, \% \mathrm{GV}$ : Relative abundance of different ecological groups

While the M-AMBI is based on a factor analysis according to the AMBI, the Shannon index H' and the specific richness $\mathrm{S}$ (Table 2).

TABLE 2. REFERENCE VALUES OF THE AMBI AND M-AMBI BIOTIC INDICES FOR DEFINING THE ECOLOGICAL STATUS OF BENTHIC HABITATS [20]

\begin{tabular}{ccc}
\hline Ecological status & AMBI & M-AMBI \\
\hline High & $0-1,2$ & $0,8-1$ \\
Good & $1,2-3,3$ & $0,5-0,8$ \\
Moderate & $3,3-4,3$ & $0,4-0,5$ \\
Poor & $4,3-5,5$ & $0,2-0,4$ \\
Bad & $5,5-7$ & $0-0,2$ \\
\hline
\end{tabular}

The AMBI and M-AMBI calculations are based on the software available on the AZTI laboratory site which is the source of these indices (http://www.azti.es) [18]. BENTIX is another biotic index developed by Simboura [21] that reduces the number of ecological groups to only 3, which reduces the uncertainty associated with the class transitions and simplifies its calculation, it evolves in the interval $[0,6]$ (Table 3 ) and it's calculated by the Equation 5:
BENTIX $=[(6 * \% \mathrm{GI})+2 *(\% \mathrm{GII}+\% * \mathrm{GIII})] / 100$

$\%$ GI, \%GII, \%GIII: Relative abundance of different ecological groups TABLE 3. CLASSIFICATION SCHEME OF BENTHIC HABITATS FROM THE BENTIX INDEX [21]

\begin{tabular}{lll}
\hline Classification-Pollution & Biotic coefficient $(\mathrm{BC})$ & $\begin{array}{l}\text { Ecological } \\
\text { status }\end{array}$ \\
\hline Normal & $4,5<\mathrm{BC} \leq 6$ & High \\
\hline Slightly polluted, transition & $3,5<\mathrm{BC} \leq 4,5$ & Good \\
\hline Moderately polluted & $2,5<\mathrm{BC} \leq 3,5$ & Moderate \\
\hline Very polluted & $2<\mathrm{BC} \leq 2,5$ & Poor \\
\hline Azoic & 0 & $\mathrm{Bad}$ \\
\hline
\end{tabular}

\section{RESULTS}

\section{A. Physico-chemical parameters}

The assessment of the physico-chemical quality of the lagoon of Moulay Bousselham was followed by the temperature, $\mathrm{pH}$, conductivity and turbidity measured at the 3 described stations. St1 recorded a $\mathrm{pH}$ of 8.57 , a temperature of $24^{\circ} \mathrm{C}$, conductivity that reach $52.6 \mathrm{mS} / \mathrm{cm}$ and a turbidity of 24.1 NTU. St 2 had a pH of 8.66 , the temperature was $22^{\circ} \mathrm{C}$, $52.6 \mathrm{mS} / \mathrm{cm}$ was the conductivity recorded for this station and the turbidity was $20.8 \mathrm{NTU}$. As for st 3 , pH was 8.71 , the temperature reached $25^{\circ} \mathrm{C}$, and the conductivity was 46.1 $\mathrm{mS} / \mathrm{cm}$ while the turbidity was $156 \mathrm{NTU}$.

This results show an homogeneity of the physicochemical parameters (temperature, $\mathrm{pH}$, conductivity) observed for the 3 stations, however the turbidity reaches a remarkable value of $156 \mathrm{NTU}$ at st 3 compared to the other stations.

\section{B. Biocenosis characteristics of habitats}

192 individuals were harvested from the different study stations. The analysis of the general taxonomic structure of benthic macrofauna at Moulay Bousselham lagoon shows the presence of 11 species, belonging to three taxonomic groups: annelids, mollusca and crustacean (Fig. 2).

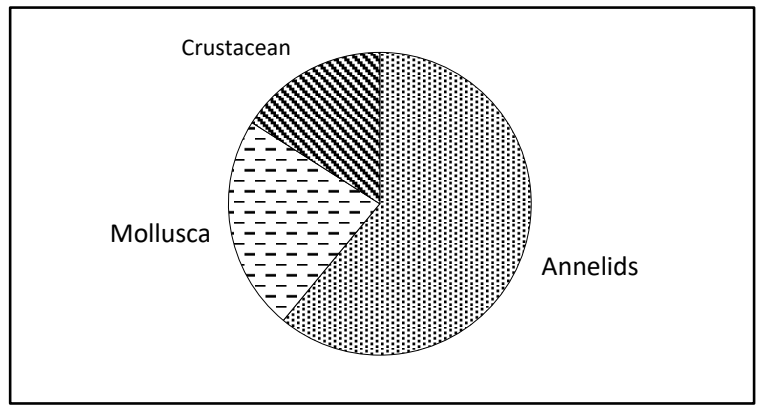

Fig. 2 Taxonomic groups, Moulay Bousselham lagoon

- $\quad$ Species richness (S), Abundance, Diversity index (H') and Pielou index $\left(J^{\prime}\right)$

At St1, abundance was 65 and we were able to identify 11 species, while 9 species were identified at $\mathrm{St} 2$ with an abundance of 84 . For st 3 , abundance was 43 and only 6 species were identified.

The results of Shannon diversity index and the equitability index obtained in the three stations are illustrated in (Fig. 3). 
St1 recorded the highest value in the lagoon (3.19 bit), followed by St2 (2.49 bit) and st3 (1.96 bit).The equitability index $(\mathrm{J} ')$ provided a value of 0.92 for st1, 0.79 for st 2 and 0.76 for $\mathrm{st} 3$.

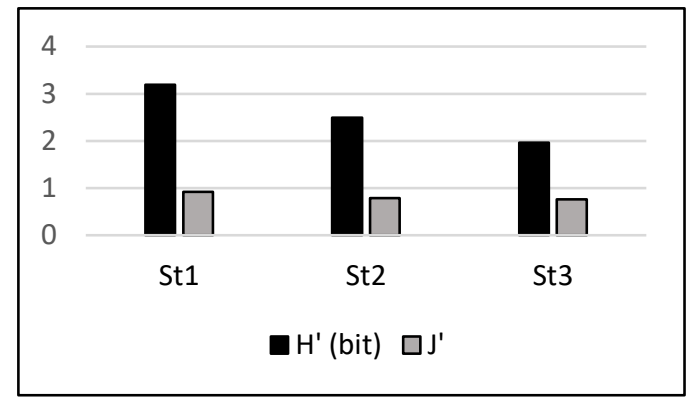

Fig. 3 Variation of Shannon index H' and Pielou index J' for Moulay Bousselham lagoon sampling stations

- $\quad$ Trophic structure

The results obtained revealed the presence of 6 trophic groups which coexist in lagoon Moulay Bousselham; The trophic groups and their abundances are shown in (Fig. 4).

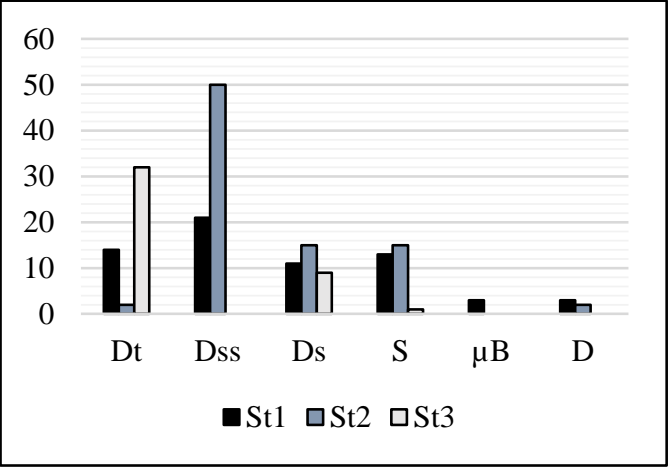

Fig. 4 Trophic organization of the benthic stand of the stations of lagoon Moulay Bousselham: Rjila, Sfiha,Laâcha

At the level of the two stations Rjila and Sfiha, the trophic group of non-selective (surface) deposit feeders (Dss) dominates; with an abundance of 21 at st1, and 50 at st2. Indeed, this group represents $32.3 \%$ and $59.5 \%$ respectively at st1 and st2, while this group is entirely absent at st3. The detritic feeders (Dt) are quite important at st1, 32 individuals were recovered, which represent $21.5 \%$ of the population recovered at this station, there abundance is low at st 2 , only 2 individuals were collected, while they dominate in st 3 with an abundance of 32 , which represents $74.4 \%$.

\section{- $\quad$ Trophic Index (TI), AMBI, M-AMBI and BENTIX}

Trophic Index (TI), AMBI, M-AMBI and BENTIX were calculated as described in materiel and methods. For St1, St2 and St 3 , the calculated Trophic Index (TI) are respectively $60.61 \%, 51.86 \%$ and $55.56 \%$ (Fig. 5). It should be noted that only the St1 has a TI that exceeds $60 \%$, a value attesting to the normality of a benthic stand.

Table 4 presents the obtained results for the AMBI index, it allows the classification of the 3 studied stations. St 3 is classified as slightly polluted according to the value of the AMBI index (3.07), while st1 and st2 are classified as moderately polluted (Fig. 6). The diagnosis of the station status according to the index is described in (Table 4).

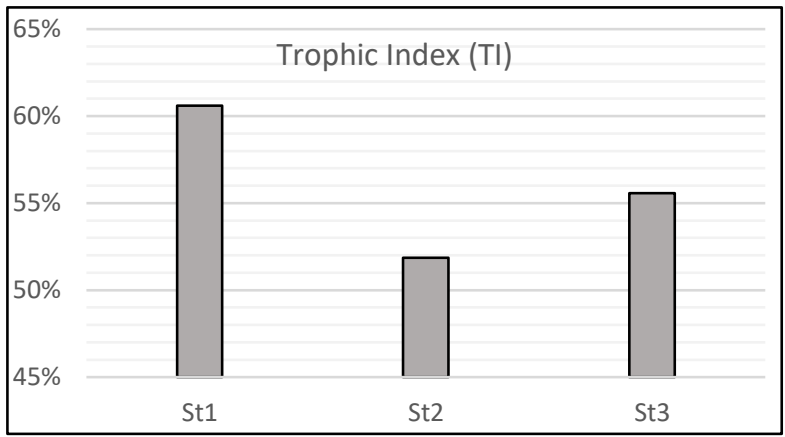

Fig. 5 Trophic Index variation of the stations of lagoon Moulay Bousselham

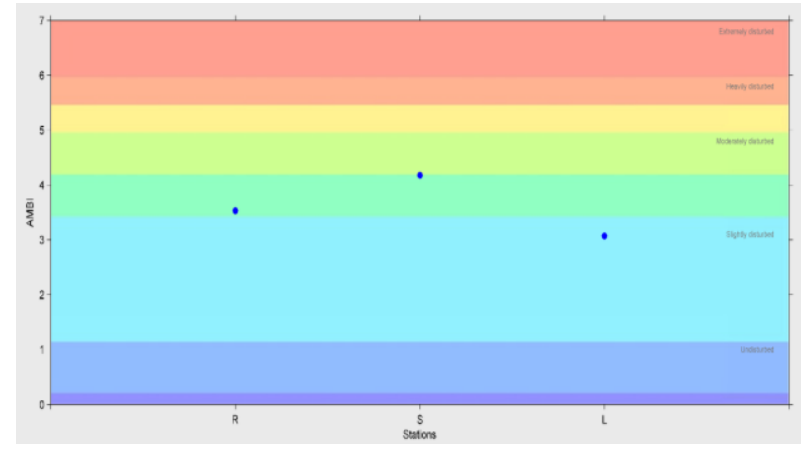

Fig. 6 Classification of the ecological quality of the 3 sampling stations according to the AMBI

The calculation of the modified AMBI index (M-AMBI) is based on AMBI, the index of diversity $\mathrm{H}^{\prime}$ and the specific richness as described in materiel and methods.

The results of M-AMBI obtained for the 3 sampling stations of Moulay Bousselham lagoon are shown in (Fig. 7).

The application of this index has classified st1 as a high quality area (0.95), compared to the two other stations which are classified as good quality area $(0.74$ and 0.71$)$.

TABLE 4. DIAGNOSIS OF THE STATE OF THE MOULAY BOUSSELHAM LAGOON ACCORDING TO THE AMBI INDEX

\begin{tabular}{|c|c|c|c|c|}
\hline Stations & AMBI & IB & Stand status & Pollution Scale \\
\hline St1 & 3.53 & 3 & $\begin{array}{l}\text { Intermediate state } \\
\text { before pollution }\end{array}$ & $\begin{array}{l}\text { Moderately } \\
\text { polluted }\end{array}$ \\
\hline St2 & 4.18 & 3 & $\begin{array}{l}\text { Intermediate state } \\
\text { before pollution }\end{array}$ & $\begin{array}{l}\text { Moderately } \\
\text { polluted }\end{array}$ \\
\hline St3 & 3.07 & 2 & imbalance & Slightly polluted \\
\hline
\end{tabular}




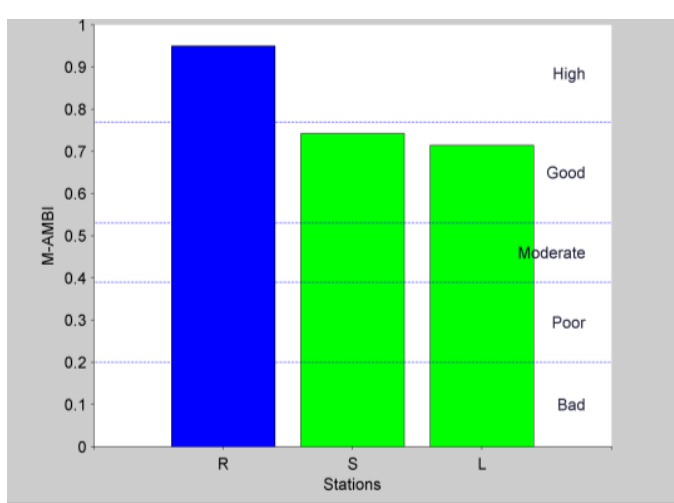

Fig. 7 Classification of the ecological quality of the 3 sampling stations according to the M-AMBI index

According to the BENTIX index values (Fig. 8), 2.18 for st1 and 2 for both st 2 and st3, st1 is classified as a poor ecological state while st 2 and st 3 have a bad ecological state [21].

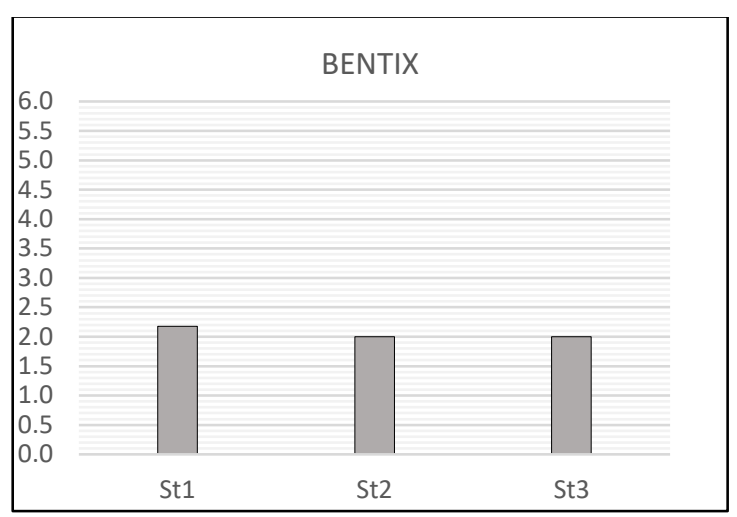

Fig. 8 Classification of the ecological quality of the 3 sampling stations according to the BENTIX index

\section{DISCUSSION}

Assessment and bio monitoring of the quality of lagoon systems uses a set of biological tools, they are based on different factors but all have the same objective: to classify zones in classes characterized for each degree of pollution. The aim of our work is to evaluate the health status of lagoon Moulay Bousselham by applying a set of indices in order to compare the information given by each.

During the sampling campaign on Moulay Bousselham lagoon to analyze the state of its bio-ecological quality, the physico-chemical parameters showed that the area is generally homogeneous in terms of temperature $\left(22^{\circ}<\mathrm{T}<25^{\circ}\right)$ and $\mathrm{pH}$ $(8,57<\mathrm{pH}<8,71)$. The turbidity values showed a clear similarity between st1 and st2 (24.1 NTU and 20.8 NTU respectively), while a significant variation was noted at st3 (156 NTU). The high level of turbidity at this station can be explained by the discharges of drainage of water from the Nador Canal in this area. On the other hand, conductivity decreases while moving away from the sea, it makes it possible to distinguish the marine sector from the freshwater sectors, and allows to translate the mineralization of the waters.

Our results shows generally that the benthic invertebrate population of the Moulay Bousselham lagoon is characterized by a low specific richness. Indeed, the taxonomic identification on 192 individuals allowed their classification in 11 species.

The benthic population is dominated in terms of species richness and abundance respectively by annelids (61\%), molluscs $(23 \%)$ and crustaceans $(16 \%)$. This structure shows a difference when compared to other studies conducted on Moroccan Atlantic lagoons. Lefrere [22] reported that Khnifiss lagoon was dominated by molluscs $(60 \%)$, lowed by polycheatea $(30 \%)$ and crustaceans $(10 \%)$, another research on Mediterranean Smir lagoon, underlines the domination of the benthic population by crustaceans $(32.4 \%)$, followed by polycheatea $(27 \%)$ and molluscs $(18.9 \%)$ [23]. Compared to other studies on Port Blair bay in India, the most abundant taxa is polycheatea $(90 \%)$, lowed by crustaceans $(5.5 \%)$ and molluscs $(2.7 \%)$ [24]. These data highlight the difficulty to determinate a characteristic structure of the benthic population of marine ecosystems.

Our results brings out a spatial variability in species richness and abundance between the three studied stations. A total abundance of 65 individuals, belonging to 11 different species, is recorded for St $1 ; 84$ individuals are classified into 9 species at St2, whereas St3 has only 43 individuals, distributed among 6 species. This suggests that abundance is not necessarily a criterion of classification of the environment since it is noted that it disagrees with the specific richness which is low.

Compared to Smir lagoon [23], the specific richness varies between 6 and 10 for each station, these values are considered as low, even if densities are high, this can be translated by the fact that a limited number of species dominate quantitatively, which can describe the population as a population of a disturbed environment [23]. The same idea is observed as for Valle di Gorino lagoon in Italy, high densities are noted will specific richness is low [25].

Shannon diversity index $\left(\mathrm{H}^{\prime}\right)$ expresses the diversity from the number of species and the abundance of individuals within each species, the index of equitability $\left(J^{\prime}\right)$ measures the distribution of individuals in the species, independently of species richness. H' and J' depend on the size of the samples and the type of habitat. According to Grall [26], $\mathrm{H}^{\prime}$ and $\mathrm{J}^{\prime}$ have low values in transition waters such as lagoons, deltas and estuaries, so it is difficult to consider them as descriptors of the state of a medium.

The Shannon-Wiener index (H') showed spatial variability between the studied stations. This confirm the variability already observed with species richness $(\mathrm{S})$ and abundance $(\mathrm{N})$. The values are quite low in the 3 stations, they vary between 1.96 (bit) and 3.19 (bit); a low value of $\mathrm{H}^{\prime}$ reflects a dominance of a group of species. Indeed, more than $53 \%$ of individuals are due to 3 dominant species, Heteromastus sp., Cerastoderma sp. and Cyathura carinata. The equitability remains comparable between the 3 stations. The maximum diversity is recorded for st1, with good equitability $(\mathrm{J} '=0.92)$, while st 3 recorded the lowest values.

The obtained results revealed the presence of 6 trophic groups which coexist in lagoon Moulay Bousselham; At the level of st1 and st2, the trophic group of non-selective (surface) deposit feeders dominates (Dss); Indeed, this group represents $32.3 \%$ and $59.5 \%$ respectively at the level of st 1 and st2, while it's absent at the st3. The detritic feeders (Dt) 
are moderately present at the st1 $(21.5 \%)$, very little at st2 $(2.3 \%)$ while they dominate at st3 $(74.4 \%)$.

Domination of non-selective (surface) deposit feeders is not quite systematic for lagoons since other trophic groups clearly dominate the communities in other lagoons, notably Smir lagoon where mainly the detritic feeders and suspension feeders dominate [27]. Studies carried out in Boughrara Lagoon in Tunisia showed the dominance of selective deposit feeders [28].

The benthic stand structure of the Moulay Bousselham lagoon is marked by a small number of species that dominate quantitatively, which means a disturbed stand [14, 23].

The Trophic Index (TI) is independent of specific wealth and indices that are based on ecological groups; it provides complementary information to these ecological rankings. The IT classifies the stand of st1 as normal, with a value that exceeds $60 \%(60.61 \%)$, it is unaffected by the enrichment of organic matter, while the st 2 and st 3 appear as unbalanced (IT $=51.86 \%$ and IT $=55.56 \%$ respectively), they are slightly affected by an enrichment of organic matter.

In this study, it appeared that the biotic indices used (AMBI, M-AMBI and BENTIX) are not correlated with each other; According to the index used, the population of the same station has an ecological state which varies between very good and mediocre, this discrepancy then raises a problem of representativeness.

According to the AMBI, the stands of st 1 and st 3 are in an intermediate state, they are moderately polluted, while st2 records a higher AMBI which tends to translate a greater imbalance than the other stations; Ecological Group III (tolerant) is present at the three stations but dominated in 2 stations, st1 and st3. Ecological Group IV (second-rate opportunists) dominates at st3. It should be noted that the opportunistic species belonging to group $\mathrm{V}$ are present mainly at st2. A low representation of this group is noted nevertheless at the other stations.

As for the M-AMBI index, the stands of the 3 stations are in good condition and therefore it translates a good quality, this index did not allow the discrimination of the stations. BENTIX, on the other hand tends to the revelation of extreme values in relation to the other indices. All the stations are in a poor ecological state, with a stand that is much polluted, the studied species. A strong agreement was detected in the responses of AMBI and TI, however the correlation of the indices with M-AMBI and BENTIX was the weakest. Agreement of AMBI and TI corresponds to the classification of species in ecological and trophic groups that have a similar sensitivity to pollution. These results have already been noted in Paranaguá Estuarine Complex [29], and for coastal and transitional ecosystems of the Eastern Mediterranean ecoregion in Greece [30], the low discrimination of BENTIX is due to the fact that species are attributed in 3 ecological groups instead of 5 groups, thus, when the community studied is dominated by tolerant species, the BENTIX index shows an ecological quality that is low compared to the AMBI. As for M-AMBI, it overestimated the quality of the lagoon, probably due to the incorporation of Shannon diversity index and species richness as metrics, without taken in account that a high value of diversity and specific richness may be due the dominance of opportunistic species [30]
It should be noted that st1 (Rjila) is an area supplied by fresh water of Oued Drader, st2 (Sfiha) is under the influence of tides since it communicate with ocean, while st3 (Laâcha) is a point of confinement, it is under the influence of water from the Nador Canal located upstream of the lagoon.

All parameters of diversity $\left(\mathrm{H}^{\prime}\right)$, equitability $\left(\mathrm{J}^{\prime}\right)$, specific richness (S) as well as trophic index (TI), reported an imbalance at some stations, and agreed that st3 is the most affected by a disturbance. According to Meissara [31] high percentages of copper, aluminum and lead are found at st3, therefore we can classify st 3 as the most polluted station in the lagoon, which can be due to the influence of Nador canal.

All the indices selected are used internationally, they have been tested and their applicability has been proven several times. The discordance present between the various indices applied to the same data have already been reported on numerous occasions [32, 33]. Many authors agreed that biotic indices should be used with caution and always in addition to other indices, such as $\mathrm{H}^{\prime}$, specific richness...). Even if the indices applied in this study have been tested and shown to be applicable in many cases, it should be noted that having a functional universal index in all systems (even if they are of the same type Ecological) is impracticable [33].

\section{CONCLUSION}

The objective of this study is to assess the health status of the Moulay Bousselham lagoon by applying a set of parameters and biological indices so that a comparison can be made between the 3 sampling stations and the indices used.

For each station, a sample was taken, the recovered fauna was sorted and identified, and then the selected biotic indices were calculated. The results of the present work led to the conclusion that Moulay Bousselham lagoon records a state of disturbance, its population is unbalanced, and this is reflected by the various indices calculated to assess the state of the lagoon, including TI, AMBI and BENTIX, which classified the lagoon in a poor ecological state, however the M-AMBI index classified the lagoon in a good ecological state.

This study contributed to the knowledge and understanding of the functioning of the benthic ecosystem at Moulay Bousselham lagoon. Finally, it should be noted that Morocco has adopted a National Biodiversity Strategy which aims to provide the general framework for clarifying actions needed for the conservation and sustainable use of biodiversity.

\section{ACKNOWLEDGMENT}

We thank ecotoxicology laboratory of National Institute of Halieutic Research (INRH) who provided insight and expertise that greatly helped, we thank H. Oubbamouh of his help during the collect of samples, and H. El Mortaji for the assistance during the treatment of samples.

\section{REFERENCES}

[1] Y. Issola, A. M. Kouassi, B. Dongui, J. Biemi, "Caractéristiques physico-chimiques d'une lagune côtière tropicale: lagune de Fresco (Côte d'Ivoire) ". Afrique Science: Revue Internationale des Sciences et Technologie, vol. 04, no. 3, pp. 368 - 393 (2008)

[2] Cépralmar, Agence de l'Eau Rhône-Méditerranée \& Corse, Région Languedoc-Roussillon, Département de l'Aude, Département de l'Hérault, Département des Pyrénées-Orientales, Défi “Eutrophisation des lagunes littorales du Languedoc-Roussillon”, Etude réalisée dans 
le cadre du sème programme de l'Agence de l'Eau RhôneMéditerranée \& Corse. 116 p (2006)

[3] Ifremer, Le bulletin du réseau de suivi lagunaire, 4 p (2000).

[4] S. Foto Menbohan, S. H. Zebaze Togouet, N. L. Nyamsi Tchatcho, A. Ajeagah Gideon, T. Njiné, "Evolution spatiale de la diversité des peuplements de macroinvertébrés benthiques dans un cours d'eau anthropisé en milieu tropical (Cameroun)". European Journal of Scientific Research, vol. 55 no. 2, pp. 291-300 (2011)

[5] O. S. Brraich and R. Kaur, "Temporal composition and distribution of benthic macroinvertebrates in wetlands". Current Science, vol. 112, no. 116, pp. 116-125 (2017).

[6] W. S. Davis \& T. P. Simon, Eds. "Biological assessment and criteria tools for water resource planning and decision making". CRC Press, 167 p. (1995).

[7] D. Bélanger, "Utilisation de la faune macrobenthique comme bioindicateur de la qualité de l'environnement marin côtier". $P h D$ dissertation, Université de Sherbrooke, 50 p. (2009).

[8] N. Desroy, L. Guerin and P. Le Mao, "Contrôle de surveillance benthique de la Directive Cadre sur l'Eau (2000/60/CE): Année 2007District Seine-Normandie" (2008).

[9] A. Qninba, A. Benhoussa, M. A. El Agbani, M. Dakki, M. Thevenot, "Etude phénologique et variabilité interannuelle d'abondance des Charadriidés (Aves, Charadrii) dans un site Ramsar du Maroc: la MerjaZerga". Bulletin de l'Institut Scientifique, no. 28, pp. 35-47 (2006).

[10] F. Ayache, J. R. Thompson, R. J. Flower, A. Boujarra, F. Rouatbi, H. Makina, "Environmental characteristics, landscape history and pressures on three coastal lagoons in the Southern Mediterranean Region: MerjaZerga (Morocco), Ghar El Melh (Tunisia) and Lake Manzala (Egypt)". Hydrobiologia, vol. 622, no. 1, pp. 15-43 (2009).

[11] L. Natij, K. Khalil, M. Loudiki, K. Elkalay, "A first attempt at seagrass repartitioning in the Moroccan coasts". International Journal of Innovation and Scientific Research, vo.10, no. 2, pp. 401-408 (2014).

[12] F. Wariaghli, A. Tilghman-Sibille, A. El Abidi, H. El Hamri, M Fekhaoui, A. Yahyaoui, "Anguilla anguilla L.: evaluation of the degree of heavy metal contamination in the Sebou estuary and in Moulay Bousselham lagoon reserve (Morocco)". International Journal of Aquatic Science, vol. 4, no. 2, pp. 69-82 (2013).

[13] H. Bazaïri, A. Bayed, M. Glémarec, C. Hily, "Spatial organisation of macrozoobenthic communities in response to environmental factors in a coastal lagoon of the NW African coast (MerjaZerga, Morocco)". Oceanologica Acta, vol. 26, no. 5-6, pp. 457-471 (2003).

[14] H. Bazairi, A. Bayed and C. Hily, "Structure et bioévaluation de l'état écologique des communautés benthiques d'un écosystème lagunaire de la côte atlantique marocaine". Comptes Rendus Biologies, vol. 328 , no. 10 , pp. $977-990$ (2005).

[15] J. Sif, A. Rouhi, P. Gillet M. Moncef, "Diversité et écologie des Annélides Polychètes du littoral atlantique de la région d'El Jadida (Maroc) ". Bulletin de l'Institut Scientifique, Rabat, section Sciences de la Vie, vol. 2, no. 34, pp. 95-106 (2012).

[16] J. Grall and M. Glémarec, "Biodiversité des fonds de maerl en Bretagne: approche fonctionnelle et impacts anthropiques". Vie et Milieu, vol. 47, no. 4, pp. 339-349 (1997)

[17] J. Q. Word, "The infaunal trophic index", Annual Report 1978, pp 19-41 (1979).

[18] CREOCEAN, Directive Cadre sur l'Eau " Eaux de Transition, Évaluation de la qualité écologique de la macrofaune benthique", Suivi des lagunes méditerranéennes en région Languedoc-Roussillon et PACA, campagne 2009, 122 p. (2010).

[19] J. Grall and M. Glémarec, "Using biotic indices to estimate macrobenthic community perturbations in the Bay of Brest", Estuarine, Coastal and Shelf Science, vol. 44, pp. 43-53 (1997).
[20] A. Borja, J. Franco and V. Pérez, "A marine biotic index to establish the ecological quality of soft-bottom benthos within European estuarine and coastal environments". Marine Pollution Bulletin, vol 40, no. 12, pp.1100-1114 (2000).

[21] N. Simboura and A. Zenetos, "Benthic indicators to use in ecologica quality classification of Mediterranean soft bottom marine ecosystems, including a new biotic index", Mediterranean Marine Science, vol. 3, no. 2, pp. 77-112 (2002).

[22] L. Lefrere, M. Ouassas, B. Guillois, P. Gillet, A. Moukrim, "Macrobenthic community structure of soft-bottom sediments in the Khnifiss lagoon, South of Morocco". Journal of Material and Envrionmental Science, vol. 6, no. 11, pp. 2226-2236 (2015).

[23] A. Chaouti and A. Bayed, "Diversité taxonomique et structure de la macrofaune benthique des substrats meubles de la lagune de Smir", Travaux de l'Institut Scientifique, Rabat, série générale, no. 4, pp. $33-$ 42 (2005).

[24] J. Equbal, G. Thiruchitrambalam, R. K. Lakra, M. Savurirajan, K. Satyam, "Assessing the ecological quality of the Port Blair coast (South Andaman, India) using different suites of benthic biotic indices". Journal of the Marine Biological Association of the United Kingdom, vol. 97, no. 5, pp. 1007-1021 (2017).

[25] M. Mistri, F. Ghion, S. Modugno, R. Rossi, "Response of macrobenthic communities to an hydraulic intervention in an enclosed lagoon (Valle di Gorino, northern Italy)". Journal of the Marine Biological Association of the United Kingdom, vol. 82, no. 5, pp. 771-778 (2002).

[26] J. Grall and N. Coïc, "Synthèse des méthodes d'évaluation de la qualité du benthos en milieu côtier", Institut Universitaire européen d la Mer. Université de Bretagne Occidentale Laboratoire des sciences de l'Environnement Marin, pp. 7-86 (2006).

[27] A. Chaouti and A. Bayed, "Structure et organisation trophique du peuplement macrobenthique de la lagune méditerranéenne de Smir (Maroc) ", Bulletin de l'Institut Scientifique, Rabat, vol. 33, no.1, pp. 1-12 (2011).

[28] I. Khedhri and A. afli, "Rôle des facteurs environnementaux et anthropiques dans la fluctuation saisonnière de l'organisation trophique de la macrofaune benthique dans la lagune de Boughrara (Sud-Est de la Tunisie) après l'extension de la passe de communication d'El-Kantra", Bulletin de l'Institut National des Sciences et Technologies de la Mer de Salammbô, vol. 43 (2016).

[29] K. M. Brauko, P. Muniz, C. de Castro Martins, P. da Cunha Lana, "Assessing the suitability of five benthic indices for environmental health assessment in a large subtropical South American estuary", Ecological indicators, vol. 64, pp. 258-265 (2016).

[30] N. Simboura and S. Reizopoulou, "An intercalibration of classification metrics of benthic macroinvertebrates in coastal and transitional ecosystems of the Eastern Mediterranean ecoregion (Greece)", Marine Pollution Bulletin, vol. 56, no. 1, pp. 116-126 (2008).

[31] A. Meissara, M. Fekhaoui, M. El Morhit, M. Waeles, A. El Abidi, A Yahyaoui, "Tissular distribution of heavy metals in the mugil cephalus of the moulay Bousselham lagoon (Morocco)", International. Journal of Science and Knowledge, Vol. 3, no. 1, pp. 18-26 (2014).

[32] R. Hermand, "Réponses d'une communauté macrobenthique méditerranéenne soumise à des apports sédimentaires allochtones naturels ou anthropiques", $P h D$ dissertation, Université de la Méditerranée-Aix-Marseille II (2008).

[33] S. Prato, J. G. Morgana, P. La Valle, M. G. Finoia, L. Lattanzi, L. Nicoletti, G. D. Ardizzone, G. Izzo, "Application of biotic and taxonomic distinctness indices in assessing the Ecological Quality Status of two coastal lakes: Caprolace and Fogliano lakes (Central Italy)", Ecological Indicators, vol. 9, no. 3, pp. 568-583 (2009). 